\title{
Kerkordelike toleransie en die reg van usansie
}

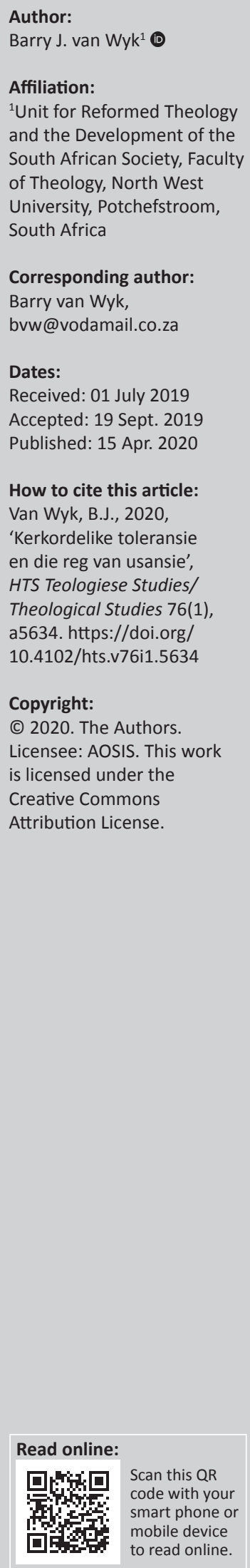

A tolerant treatment of church order and the law of usance. This article discusses the recent decline of church polity in the Netherdutch Reformed Church which is obvious in different areas of the Church with special reference to the liturgy practised in sermons of some congregations. This decline is also observed in other churches in South Africa and abroad. The article is a reaction to the reason for this situation and indicates that it should not be found in a collegialistic concept of church, but rather due to congregationalism or independentism in modern form. The article's viewpoint is that the above-mentioned church polity decline is a result of the fact that church order is not valued as an order with a Scriptural and therefore an ecclesiological basis.

Keywords: tolerance; usance; collegialism; independentism; ecclesiology.

\section{Inleidend}

Gesien vanuit die verskillende teologiese vakgebiede wat tradisioneel in teologiese fakulteite aangebied word, kan die bewering gemaak word dat kerkreg nie soveel belangstelling geniet soos byvoorbeeld die Bybelwetenskappe nie. Beoordeel vanuit die gemeentelike praktyk egter, vorm kerkreg in sy wydste verband, eintlik deel van die kerklike lewe sonder dat dit sodanig waardeer word. Dit word veral op die spits gedryf wanneer verskil van mening oor kerkregtelike aangeleenthede ontstaan. Tog bestaan die gewaarwording dat kerkreg in die meer onlangse verlede minder aandag geniet en dat ampsdraers en vergaderings van die ampte, nie uitsonderlik rekening hou met kerkordelike formulerings soos dit in die kerkorde teruggevind word nie. Meegaande artikel wil die vraag beantwoord waaraan die toestand te wyte is. Dat dit nie net in die eie kerk bestaan nie is duidelik uit die opmerkings van Koffeman (2009:10) in Nederland en Smit (2018) in Potchefstroom.

\section{Kerkregtelike gewaarwordinge vanuit die eie Kerk}

Kerklike omgang en meelewing tussen ampsdraers en vergaderings van die ampte lei dikwels tot die gewaarwording dat kerkordelike maatreëls hedendaags as nie besonder bindend geag word nie. Die siening is veral op liturgiese gebied in die Kerk waarneembaar in die sin dat soms redelik sterk afgewyk word van die kerkordelike verwagting soos geformuleer in Ordereël 5.3.1 dat die liturgie die eenheid van die Kerk dien en die identiteit en etos van die Kerk bevorder (eie beklemtoning) (Nederduitsch Hervormde Kerk van Afrika [NHKA] 2016:69). Dié mening op grond van die feit dat die kansel uit sommige gemeentes verwyder is, die dominee nie net sonder 'n toga die Woord bedien nie, maar ook met kleredrag wat dalk nie uiting gee aan die waardigheid van die amp eie aan die etos van die Kerk nie (vgl. 'Die erediens in die NHKA' 2019:7).

Behalwe op liturgiese gebied in die Kerk kan ook na die ampte verwys word waar daar veral op die vlak van die presbiteraat klaarblyklik' $n$ verleentheid ontstaan het in die sin dat ouderlinge tot die kerklike kantlyn verwyder geraak het, tydens eredienste moontlik nog in die banke afgesonder vir ouderlinge sit en nog as voorleser tydens eredienste optree (vgl. Ordinansie 5.3.3) (NHKA 2016:72).

Verder kan veral verwys word na die ringsvergadering waar die indruk ontstaan het dat dié vergadering jaarliks plaasvind waar ringskommissies aangewys word, maar nie daarna voldoen aan die kerkordelike verwagting (Ordinansie 4.3.2) dat ringskommissies verder mutatis mutandis optree in die plek van die ringsvergadering wanneer die ringsvergadering verdaag het en nie meer in sitting is nie (NHKA 2016:53).

Sodoende kom weinig tereg van 'n deel van die ringskommissie se opdrag om visitasiekommissies te benoem om leiding, toerusting en motivering aan ampsdraers in die ring te verleen en vanuit die Bybels-reformatoriese teologie oor die opbou van gemeentes en hervorming van gemeentelike 
praktyk te besin volgens Ordinansie 4.2 .2 (vii) en (viii) (NHKA 2016:49).

In 'n skrywe van die Sentrum vir Gemeentelike Bediening binne die raamwerk van die Hervormde Teologiese Kollege het 'n skrywe gedateer 15 Mei 2018 (13/2018) die lig gesien wat handel oor streeksleiers wat op 09 Februarie 2018 deur die Moderamen genomineer is om as:

[F]asiliteerders binne die Sentrum vir Gemeentelike Bediening toegerus te word vir hulle voortgesette dienswerk binne die werkruimte van die NHKA. Besluit 27 van die 71ste Algemene Kerkvergadering versoek dat die Kerk deurlopend aandag gee aan die ontwikkeling van leierskap. 'n Proaktiewe benadering tot die begeleiding van gemeentes en ringe is dié benadering wat gemeentes in staat gaan stel om betyds die nodige aanpassings te doen ten einde die uitdagings van ons tyd te oorleef. (NHKA 2018:1)

Die vraag ter tafel is of leierskap in die Kerk (vgl. Smit 2018:6) so noodsaaklik is en hoe die verband tussen 'n geroepe bedienaar van die Woord en 'n leier in die Kerk gesien moet word, of selfs kan saamval. Is 'n gebrek aan goeie leiding in die kerklike lewe tiperend van 'n leemte in die opleiding, of is teologiese opleiding, geroepenheid as dienaar van die Woord nie noodwendig bruikbaar in diens van goeie kerkleiding nie? Wat stel die Kerk met leierskap in die vooruitsig wat nie ook deur ringskommissies hanteer kan word nie en waarom is dit nodig om vanuit sinodale vlak bykomstige strukture te skep om in gemeentes die nodige aanpassing te doen, om die uitdagings wat aan die kerklike lewe gestel word, die hoof te bied?

Dat gemeentes op stoflike gebied, veroorsaak deur verskillende redes, in die noute beland wat ongewilde besluite verg, is kenmerkend van veranderde tye. Dit het in die verlede ook gebeur, daarom maak die kerkorde voorsiening vir die afskaling van die predikant se werkopdrag vanweë finansiële redes volgens Ordinansie 3.2.3.2(i) (NHKA 2016:22). Sodanige optrede word ook in die korporatiewe wêreld aangetref en geskied gewoonlik op 'n basis van laaste in, eerste uit. Daarom sou verwag word dat laasgenoemde Ordinansie sonder teenspraak in die Kerk gevolg sou word, gesien in die lig van die feit dat kerkordelike maatreëls dikwels verby gegaan word met ' $n$ beroep op die burgerlike wetgewing. Derhalwe is dit vreemd dat gemeentes in die verband eerder die weg van batestroping volg wat tot gevolg het dat gemeentelike vaste eiendom eerder verkoop word om standplaaskoste die hoof te bied.

As eiesinnige optrede deur betrokkenes in meegaande verband kan ook verwys word na die debat tydens die eenen-sewentigste Algemene Kerkvergadering met betrekking tot die deelname van kinders aan die Nagmaal en deelname van persone wat buite die grense staan van die uitnodiging tot die Nagmaal wat in die Hervormde Kerk gebruiklik is. Miskien is die kerklike skeuring wat deur die sogenaamde steedsHervormers veroorsaak is sedert die nege-en-sestigste Algemene Kerkvergadering, die mees radikale voorbeeld van kerkordelike eiesinnigheid.
Die artikel wil in die lig van die kerklike lewe in die huidige tydsgewrig soos dit ervaar word in die Nederduitsch Hervormde Kerk van Afrika in besonder, poog om vas te stel waarom kerkordelike maatreëls, nader besien, die kerkorde en derhalwe ook die kerkreg as deel van die teologiese kurrikulum, nie besonder wye belangstelling geniet nie. Dat toegespitste studie in kerkreg nog nooit wye belangstelling geniet het nie is gemeengoed, maar is dit ook aanvaarbaar dat die kerkorde, asook kerkordelike maatreëls wat driejaarliks tydens die Algemene Kerkvergadering (soos die sinodale vergadering in die NHKA bekend staan) vasgestel word, klaarblyklik nie noodwendig meer rigtinggewend in die Kerk is nie?

Kritieke vrae kom in die verband ter tafel, soos dat dit dalk nie so erg is nie, gelaat kan word, tipies van 'n bepaalde tydsgees is, of dat die kerkreg en in die verlenging daarvan die kerkorde, ver verwyderd is van die kerklike ervaring van die deursnee lidmaat. Dalk nog meer krities is die vraag waarby uiteindelik geland word, naamlik die relevansie van die Bybel as Woord van God in die lewe van hedendaagse ampsdraers en lidmate in die lig van die feit dat 'n kerkorde in Skriftuurlike lig funksioneer.

Kommer in dié verband is nie vergesog nie, aangesien 'n kerkorde ekklesiologie is en daarom Skriftuurlik gefundeer is wat binne die ruimte van 'n kerk van Reformatoriese oorsprong, nie kosmeties of bykomstig geag kan word nie. Koffeman (2009:10) tipeer die lukraak reaksie en omgang met die kerkorde en kerkordelike maatreëls as 'n 'forse argwaan tegen kerkrecht'. Anders gestel: die inhoud van 'n kerkorde is tiperend van die teologie wat op 'n gegewe moment in die betrokke kerk bepalend was (Koffeman 2009:13). In die verband maak Koffeman (2009) die volgende opmerking:

Het lijkt me dat de Schrift in het kerkrecht primair een rol zal moeten spelen om het perspectief scherp te krijgen waarbinnen we ook vandaag over de kerk - en dus over haar recht - kunnen spreken [...] waartoe bestaat de gemeente eigenlijk? Hoe staat zij in het verlengde van de beweging die rond Jezus Christus zichtbaar wordt? (p. 15)

Koffeman (2009:101) verwys na die band tussen sigbare en onsigbare kerk as die mees sentrale vraag van die ekklesiologie. Hoe moet die koppeling tussen die grond, wese en eienskappe van die kerk as onsigbare aspekte gesien word in vergelyking met sigbare aspekte soos die struktuur van die kerk en nader besien, die kerkreg as een van die vorme waarin die kerk sigbaar word? Krities beskou: Welke betekenis het, wat geglo en bely word oor die kerk, vir kerkordelike reëlings?

Die relasionele verhouding tussen Skrif, belydenis en kerkorde onderskei 'n kerkorde as ekklesiologie en ontneem die kerk, sy lidmate en ampsdraers die eiesinnige en halsstarrige neiging om slegs in eie reg en mening op te tree. Prakties gesproke kom dit daarop neer dat daar nie voortdurend slegs met die kerkorde rekening gehou moet word nie, maar skerper gesien met die Skrif, in die lig van die Dingemans (1988:207) uitspraak dat die kerkorde in regsreëls vertaalde ekklesiologie is. 'n Kerkorde wat nie Skriftuurlik veranker is nie het verword tot die vlak van die konstitusie van net nog 'n sosiale vereniging. 


\section{Omgang met 'n kerkorde}

Omgang met 'n kerkorde verg noodwendig van die leser dat met die kerkorde, soos uiteengesit en geformuleer in verskillende gedeeltes, wat van kerk tot kerk kan verskil, versigtig omgegaan sal word. Die Kerkorde van die Nederduitsch Hervormde Kerk bestaan uit tien hoofstukke wat elk uit twee afdelings bestaan, onderskeidelik as Ordereëls en Ordinansies wat nie dieselfde gesag dra nie en nie op dieselfde manier tot stand kom nie, maar in mekaar se verlenging funksioneer. Die Noordmans (1984:444) uitspraak bly steek, naamlik dat ' $n$ kerkorde tiperend is van kerklike denke as voorwaarde vir kerklike optrede, wat ongeag verskillende interpretasies van die Skrif, nie los gemaak kan word van die Woord van God as bron van sola fide nie.

Om die rede gaan dit om gehoorsaamheid deur die geloof aan die hoof van die kerk, Christus. Die apostels en almal wat daarna gevolg het, is niks anders nie as verbi divini ministri, dienaars van die Woord. Die Woord van God bly dus bindend in die diens van ampsdraers (vgl. Matt 23:8-10) om uiting te gee aan die Christus teenwoordigheid in die kerk. Maar in die gehoorsaamheid aan die Woord setel ook volkome vryheid van bloot menslike wette, tradisies en ideologieë (vgl. 2 Kor 3:17; Gal 5:1,13). 'Zou deze dialactiek van gebondenheid en vrijheid ook niet wezenlijk voor iedere "schriftuurlijke kerkorde" zijn?' (Bronkhorst 1988:46).

Dit gaan in die kerk om ' $n$ christokrasie wat nie sinoniem is met demokrasie, aristokrasie, monargie, 'n diktatuur of waarmee die lysie uitgebrei kan word nie. Die Kerk funksioneer binne die ius circa sacra, die omgewing van die burgerlike regspleging, maar die ius in sacra wat in die Kerk beoefen word, word daarom nie demokraties van aard waar die meerderheid van stem bepalend is nie (Bronkhorst 1988:45). Daarmee moet kerkreg ook nie gesien en hanteer word as in verlenging van die burgerlike regspleging, geldig in die land waarin die Kerk bestaan nie.

Die omgang en blootstelling, asook die hantering van 'n kerkorde, word as kerkordelike hermeneutiek tipeer wat van besondere en wesenlike waarde is, net soos omgang met die Skrif en belydenisskrifte, asook in regstekste gevind word (vgl. Le Roux du Plooy 2012; Van de Beek 1988; Van Wyk 2004:150-152). Daar is dus 'n rede waarom 'n kerkordelike maatreël noodwendig só geformuleer is soos weergegee in 'n bepaalde kerkorde van 'n kerk. 'n Kerkorde staan as't ware op die weg tussen Bybel en praktyk as spieëlbeeld van hoe die kerk oor homself getuig in die lig van die Skrif.

Nogmaals moet daarop gewys word dat die burgerlike regspleging nie die agtergrond en maatstaf vorm waarteen die kerkorde uitgelê en verstaan word nie. 'n Kerkorde is nie 'n stuk wetgewing wat soos burgerlike wetgewing, rigied gehoorsaam moet word nie (vgl. Van Wyk 2004:147), alternatiewelik, strafbaar is deur die owerheid wat oor die ius gladii beskik nie (Plomp 1969:73). Dat sommige hulle tot die burgerlike wetgewer wend in kerklike verskille is deel van die hedendaagse kerklike uitwasse wat kerklike optrede ontsier en nie die gevolg is van kerklike denke nie. In die lig van die feit dat Jesus Christus hoof van die kerk is (vgl. Ef 1:22, 23; Kol $1: 18$ ) sou die beroep op ampsdraers en lidmate gedoen kon word om tog te gehoorsaam, om Jesus wil, in die lig van die feit dat die kerkorde ekklesiologie is (Van Wyk 2018:8).

Dit is ten minste wat die Kerkorde van die NHKA betref, ook belangrik om in gedagte te hou dat in die formulering van die Kerkorde uitgegaan is van 'n maksimum-minimum uitgangspunt wat daarop neerkom dat 'n kerkordelike riglyn getrek word as kerkorde vir die héle Kerk en nie net vir 'n bepaalde gemeente nie. Juis om hierdie rede is interpretasie van die Kerkorde van wesenlike belang wat ten minste 'n bepaalde kerklike (kerkregtelike-) behendigheid verg.

\section{Kerkordelike toleransie}

Die hermeneutiese aanslag in die benadering en gebruik van 'n kerkorde lei waarskynlik daartoe dat negatief gesproke onder die indruk verkeer kan word dat 'n kerkorde na goeddunke toegepas kan word of nie, wat eventueel kan uitmond in 'n kerklike praktyk wat daarop neerkom dat ampsdraers en vergaderings van ampte hulle eie weg gaan. Dit sou ' $n$ onderwaardering van kerkordelike hermeneutiek beteken omdat laasgenoemde nie gelyk is aan suspendering van kerkreg en kerkorde nie. Verwysing na die Skrif en belydenis van die kerk dui juis op 'n bewustelike omgang met kerkordelike maatreëls wat daarop neerkom dat van harte gepoog word om uiting te gee aan wat genoem kan word 'n kerkordelike kerklikheid.

Met verwysing na liturgie moet beklemtoon word dat die bedoeling nie is om alles terug te voer tot die verlede wat op 'n totale verstarring sou neerkom nie. Daarom word nie stelling ingeneem teen verandering nie, maar daar kan seker in die vooruitsig gestel word dat verandering en vernuwing met verdieping gepaard gaan en nie vervlakking tot gevolg sal hê nie. Daarom is daar nie slegs een geformuleerde liturgiese kerkordelike model nie, maar word ruimte gelaat vir die liturg om die erediens in te klee binne die etos van die Hervormde Kerk.

Die kritieke vraag is egter wanneer die grense van kerkordelike hermeneutiek bereik word en die betrokke kerklike praktyk sodanig verword het dat dit nie meer te rym is met etos, toelaatbare toleransie of optrede in die lig van die Skrif en belydenis nie. Dit is waarskynlik nie korrek om kerkordelike hermeneutiek en kerkordelike toleransie teenoor mekaar te stel nie, maar liewer dat toleransie as afwyking van die geformuleerde besluit of kerkordelike maatreël slegs aanvaarbaar is wanneer sodanige afwyking die resultaat is van 'n hermeneutiese omgang met die kerkorde en wat daarmee saamhang. Prinsipieel beskou kan toleransie slegs ingebed wees in ' $n$ bewuste kerkordelike hermeneutiek. Derhalwe is toleransie nie moontlik as bloot belangelose eiesinnigheid nie.

\section{Die reg van usansie}

Die reg van usansie staan geformuleer binne die gedeelte van die Kerkorde van die NHKA(Ordereël 4) waar die verskillende 
vergaderings van die ampte behandel word as deel van die uitgangspunte op grond waarvan besluite deur vergaderings van die ampte geneem word. Ordereël 4.1 verwys in rangorde soos verwag kan word na die Bybel, die belydenis van die Kerk en die Kerkorde, maar voeg dan by: 'met inagneming van die gebruike van die Kerk' (NHKA 2016:42).

Die reg van usansie kom ook in Ordereël 10.5 (NHKA 2016:98) voor waar nader gepresiseer geargumenteer word dat dit gaan oor noodsituasies waarvoor die Kerkorde nie voorsiening maak nie en besluite geneem kan word, gebaseer op die Skrif en in ooreenstemming met die belydenis van die Kerk, getrou aan en met inagneming van die gebruike van die Kerk. Die situasie word kerkordelik ondervang en voorsien volgens Ordereël 10.5, dat situasies mag opduik waarvoor die Kerkorde nie voorsiening maak in presiese woorde nie en 'n interpretasie derhalwe nodig is. Die inhoud van Ordereël 10.5 strek wyer as net die onverwagte, maar moet as hermeneutiese sleutel van toepassing gemaak word op die Kerkorde as geheel. Ordereël 10.5 handel sodoende nie net oor die reg van usansie en wat dit beteken nie, maar is tegelyk ook die grense van 'n kerkordelike hermeneutiek. Dit kan as die Kerk se (kerkregtelike) voorreg gesien word om besluite op grond van die Skrif te neem.

Die reg van usansie kom eenvoudig gesproke daarop neer dat kerkregtelik' $n$ saak daarvoor uit te maak is dat' $n$ kerkordelike praktyk deur die loop van tyd in die kerk algemeen geword het, sodat iemand wat in sodanige praktyk volhard, nie daaroor onder kritiek geplaas kan word nie. Hier gaan dit nie oor kerkordelike praktyke wat in die kerkorde geformuleer is, of wat deur die Algemene Kerkvergadering vasgestel is nie, maar juis handelinge waaroor die kerk nie amptelik besluit het nie. Dit kom dus daarop neer dat kerkordelike toleransie en die reg van usansie dalk nader aan mekaar funksioneer as wat vermoed word, aangesien kerkordelike toleransie wat bewus of onbewustelik toegelaat word, uiteindelik onder die vaandel van die reg van usansie kerklike praktyk(mag) word wat nie meer sensurabel geag kan word nie, bloot omdat dit toegelaat is. 'n Bepaalde praktyk wat posgevat en nagevolg word is net omdat dit toegelaat word, nie noodwendig wenslik vir die kerk nie en nie noodwendig gelyk aan 'n hermeneutiese omgang met die kerkorde nie.

Dit beteken dus nie dat kerkordelike hermeneutiek en kerkordelike toleransie aan mekaar gelyk is nie. Die reg van usansie en praktyke wat daaruit voortvloei is gebaseer op 'n hermeneutiese omgang met die kerkorde, gefundeer op die Skrif en belydenis van die kerk, terwyl toleransie gewoon sy oorsprong vind by 'n afwykende en argelose omgang met die kerkorde. Toleransie is dus onkerkordelik en vir die kerk nadelig omdat die oorsprong daarvan waarskynlik buite 'n kerkordelike hermeneutiek sy oorsprong vind. Die kerk moet dus daarop bedag wees om met fyn diskresie te onderskei tussen praktyke wat op 'n verantwoordelike kerkordelike hermeneutiek gebaseer is en selfs met verloop van tyd praktyk geword het, teenoor toleransie wat die gevolg is van onkerkordelike omgang, toegelaat word en langsamerhand poog om as kerkordelike praktyk erken te word.

\section{Kerkorde in praktyk}

Dit is 'n vraag of dié punt, soos gestel in bogenoemde opmerking, ten minste op die gebied van die liturgie in die NHKA, nie reeds bereik is nie. Die opmerking word soms gehoor dat die kerkorde die Kerk se grootste probleem is en dat krities gevra word, of persone onder die indruk verkeer dat alles by wyse van spreke tot Genève, na Calvyn teruggevoer moet word. Niks daarvan is waar nie, net so min as wat onder die indruk verkeer word dat die handelinge van die verlede sonder meer saligmakend is en dat by wyse van spreke kerkordelik met die Dordtse Kerkorde wat in 1618-1619 vasgestel is, volstaan moet word.

Die kerkorde word in dié verband soos die Skrif hanteer, in die sin dat telkens teruggevra word en nie onder die indruk verkeer word, selfs nie eers by implikasie nie, dat die Skrif eenmaal ter sprake gebring is en derhalwe volstaan word met 'n verstarde verstaan van die Skrif soos in die verlede vasgestel en daarom algemeen geldig is vir tyd en ewigheid. Die uitdaging in dié verband is ten minste om ou waarhede nuut te formuleer. Dit is ' $n$ ou belydenis wat in 'n nuwe situasie coram Deo anders en nuut gesê word. 'Die kerk is immers geroepe om onder nuwe omstandighede, binne sy eie geloofstradisie, die paradoks van die Woord wat mens geword het, opnuut te deurdink en te bely' (Koekemoer 1994:23). Die kerkorde is dus nooit finaal nie en wesenlik kom dit daarop neer dat 'n kerkordelike dispuut 'n Skriftuurlike argument word.

Koffemann (2009:89) verwys na Torfs wat daarop wys dat selfs wanneer kerkordelike maatreëls uiteindelik as formulering in die kerkorde opgeneem is, die laaste woord nie gespreek is nie omdat die geldende en geformuleerde reg voortdurend geëvalueer moet word wat hy bestempel as die 'kritische blik achteraf'. 'n Kerkorde word nie positivisties hanteer in die sin dat slegs bepaal word of aan die geformuleerde reg voldoen is soos dit eenmaal geformuleer is, al dan nie. Tegelyk word ook natuurregtelik na die geformuleerde wetgewing gekyk in die vraag of die bepaalde maatreël billik en korrek is nie. 'Voor het rechtspositivisme is de aanspraak op gezag doorslaggevend, voor het natuurrechtelijk denken veeleer de aanspraakop juistheid' (Koffeman 2009:86). Kerkordelike maatreëls kan ook nie aanleiding word vir 'n soort kerklike geweld waardeur op grond van die geformuleerde reg 'n geweldsmonopolie (Koffeman 2009:88) ter sprake kom wat veral geneig is om te manifesteer in die manier hoe voorsitters, benoemde funksionarisse en kleiner kontinuerende kommissies, geneig is om die besluite van vergaderings in die praktyk ten uitvoer te bring nie.

Die eis tot kerkordelike meelewing en uitvoering is dus nie geleë in die kerkorde as sodanig nie, maar inderdaad om Christus wil in die sin wat in die bestaan van ' $n$ kerkorde geïmpliseer en veral onder kerk verstaan word.

\section{Moontlikhede van rekenskap}

Wanneer diekerkordelike verlede uit die Bybels-reformatoriese tradisie nagegaan word, is dit opvallend dat die neiging tot kerkordelike ordening sover teruggevoer kan word tot die 
Didaché of Leer van die twaalf apostels wat selfs nog voor die einde van die eerste eeu na Christus ontstaan het. Die wetenskaplike beoefening van kerkreg dateer omstreeks uit die twaalfde eeu (Bakker 1988:20). In dié verband kan ook verwys word na vroeë Katolisisme (Frükatholizismus), 'n begrip wat in die twintigste eeu geformuleer word met betrekking tot 'n debat wat uit die vorige eeu dateer en gevoer is deur Bauer en Schweitzer vanuit Tübingen. Dunn (2010) wys daarop dat Katolisisme:

[E]merged when the charismatic organization which characterized the earliest Church gave way to institutionalization, where the institution was identified as Church with all which that meant in terms of authority of office and ecclesiastical law. (p. 374)

Die kerkregtelike gang kan gevolg word sedertdien, dwarsdeur die Reformasie van die sestiende eeu, die Nederlandse tradisie wat Reformatoriese kerke in SuidAfrika as agtergrond het (vgl. Oostenbrink-Evers 2000:21-40), tot op datum. Die Nederlandse kerkregtelike stryd sedert 07 Januarie 1816 tot 01 Mei 1951, toe die Nederlandse Hervormde Kerk uiteindelik die Algemeen Reglement van 1816 vervang het (Oostenbrink-Evers 2000:19, 279), toon die belangrikheid van kerkreg as ekklesiologie aan wat uiteindelik tot kerklike welwese in 'n kerkorde neerslag vind. Dit was as 't ware vanselfsprekend vir die kerk oor eeue heen om oor 'n kerkorde te beskik en derhalwe kerkreg te beoefen.

Derhalwe kan lank en breed geargumenteer word oor kerk en alles wat daarmee saamhang in breedste verband. By alles moet belydend bevestig word dat daar slegs een kerk in die bewoonde wêreld is. Alle verskillende kerke poog om 'n verskyningsvorm van die ware kerk te wees waarvan in die Apostolicum sprake is. Dit hou in dat die uitdaging nooit minder akuut word nie om seker te maak dat die kerk, ook die eie kerk, al meer kérk sal word. 'Want daarom gaan dit uiteindelik: nie om teoreties te weet wat kerk is nie, nie om 'n definisie van die kerk nie, maar om kerk te wees' (Oberholzer 1999:460).

Verleentheid rondom toepassing en waardering van die kerkreg en kerkorde is dus nie beperk tot een kerk nie, inteendeel. Die vraag waarom kerkreg en kerkorde nie deesdae die nodige klem ontvang en gestalte vind in 'n entoesiastiese meelewing in alle kerklike fasette van bestaan nie, kom ook buite die eie Kerk ter sprake.

Ten spyte van die matige kerkordelike onvergenoegdheid wat hedendaags in die kerk beleef word, gebeur dit teen 'n besondere kerkordelike verlede wat eie aan die kerk is sedert die vroegste tye, sedert die koms van Christus. Die saak is eintlik besonder eenvoudig, omdat dit nie anders kan nie wanneer getalle meer word as net die self en 'n onderneming tussen deelgenote nodig word wat die onderlinge verhoudinge reël. Dit is presies wat 'n kerkorde wil doen, maar nie gegrond op die belang van die groep in eerste instansie nie, maar in Skriftuurlike lig, aangesien die begrip kerkorde, kerk impliseer.

\section{Kollegialisme}

Met betrekking tot Kollegialisme kan verwys word na Smit (2018:1) se mening wat die afname en onderwaardering van kerkreg vind in 'the dominant collegialistic concept of church since the acceptance thereof in South Africa.' Hy is van mening dat Kollegialisme die dominante siening van die kerk in SuidAfrika is wat na vore kom in 'permanent synodical structures, executive committees and permanent structures' (Smit 2018).

Hy stel die saak verder in sy siening dat die kerk:

$[I] \mathrm{s}$ a mere human society (societas), a society equal (societas aequalis) to all other societies within the state borders [...] viewed as a result of the free will of man - an expression of man's desire to give expression to his religious feelings. In this view of the church, the creation of the church fundamentally subsists with man. (p. 2)

Die mening word sterker gestel in die verdere opmerking dat die 'hallmark of Collegialism is that church government finds its point of orientation not in Scripture, but in state government' (Smit 2018:3).

Die debat oor Kollegialisme kan teruggevoer word tot die aanvaarding van die Algemeen Reglement van 1816 wat deur die Koning Willem I, met die toedoen van staatssekretaris J.D. Janssen op die Nederlandse Hervormde Kerk afgelaai word (Oostenbrink-Evers 2000:28-31). Daar is geen aanduiding dat Janssen kennis geneem het van die grondslae van die Kollegialisme nie (Brown 1992:701; Pont 1991:125). Die siening dat die Algemeen Reglement van 1816 onder invloed van die Kollegialisme tot stand kom is 'n agterhaalde mening van De Wet (1921:70) en Kuyper (1884:51) waaroor reeds kommentaar gelewer is (vgl. Pont 1991:110-131; Van Wyk 1991:112-122) en sover bekend nie weerlê is nie.

Oor die onaanvaarbaarheid van die Algemeen Reglement van 1816 hoef nie debat gevoer te word nie en die stryd wat die Nederlandse Hervormde Kerk in dié verband gevoer het dui daarop, veral gesien in die konteks waarbinne die weerstand plaasgevind het. Die kern van die saak was dat die Algemeen Reglement die kerk wou bestuur, want die kerk is as 'n genootskap gesien (vgl. Kleyn 1888:193-195) waardeur die kerk vervlak is tot nóg 'n sosiale vereniging in die gemeenskap (Oostenbrink-Evers 2000:34) waaraan lidmate vrywillig toetree en ook vrywillig die kerk verlaat het. Kenmerkend van die Algemeen Reglement was 'n hiërargiese bestuurstelsel wat sinodaal gevestig en daarna afgewentel is na die gemeente (Art. 3) (Hooijer 1848:25).

Want in Artikel 16 word aangedui dat die hoogste kerklike bestuur opgedra is aan die sinode. Hoewel in Artikel 9 (Hooijer 1848:26) sprake is van die handhawing van die leer van die kerk, was dit nie noodwendig die intensie van die kerklike bestuur om leeruitsprake te maak nie (vgl. Fiolet 1953:27; Oostenbrink-Evers 2000:30). Hierin word laasgenoemde en die aankweking van liefde vir koning en vaderland naas mekaar geplaas as deel van die belang van die kerk in besonder [sic]. 
Die Algemeen Reglement is nie die resultaat van die Kollegialisme wat die gevolg is van die rasionalisme, 'n vrug van die Duitse Aufklärung nie. Kenmerkend van die stelsel was sy kollegiale karakter, 'n vereniging van mense wat saam besluit om 'n kerklike gemeenskap te vorm (vgl. Schlaich 1969:14-16). Sodoende is die kerk soos enige ander sosiale vereniging, nie van Goddelike oorsprong en nie deur Christus ingestel nie (Bouwman 1937:14). Die oorsprong van die kerk by die Kollegialisme is die resultaat van vrye mense wat byeenkom om 'n kerk te vorm:

$[D]$ ie dan niet anders is dan een door verdrag geboren collegium [vandaar die naam van die stelsel] in den staat. [...] De kerk valt geheel onder de rechtsbepalingen, die voor allerlei vereenigingen gelden. (Biesterveld \& Kuyper 1905:x)

Die fout van die Kollegialisme was dat die kerk as 'n bloot menslike vereniging beskou is waarvan die gesag en ook uiteindelik die struktuur die resultaat is van die deelnemers (Coertzen 1991:216).

Verder het die Kollegialisme nie owerheidsinmenging in die kerk verdra nie want in die agtergrond moet die Territoriale of Consistoriale stelsel in gedagte gehou word waar die naam van Thomas Erastus ook ter sprake kom (vgl. Coertzen 1991:214-215) waar die owerheid die kerk regeer het (Biesterveld \& Kuyper 1905:v-ix). Dit is juis die rede vir die ontstaan van die Algemeen Reglement, danksy Koning Willem I en Janssen, derhalwe teen die grein van die Kollegialisme in. Die Kollegialisme was 'n regstelsel wat uitgedink en toegepas is ooreenkomstig oorwegings en aannames eie aan die Verligting. Kerke moes van staatsoorheersing bevry word en daarom is gebruik gemaak van die verenigingsreg omdat gedink is aan enkelinge wat op grond van verdrae verenigings met mekaar sluit (Brown 1992:695).

Die reglynigheid waarmee die Kollegialisme as kerkregtelike stelsel op Duitse bodem sonder meer op die Algemeen Reglement van 1816 toegepas is, is waarskynlik eerder te verklaar vanuit die kerklike spanning wat op die invoering van die Algemeen Reglement gevolg het en uiteindelik twee kerklike afskeidings tot gevolg gehad het. Sover bekend word dieAlgemeen Reglementnie deur diegene wat'n belangstelling in kerkreg het, verdedig nie (vgl. Pont 1991:107). Wie die Algemeen Reglement en die Kerkorde van die Nederlandse Hervormde Kerk van 1951 naas mekaar plaas, sal tot die slotsom kom van die onbruikbaarheid van die Algemeen Reglement, asook hoe sterk die Nederlandse Hervormde Kerk hom daarvan gedistansieer het. Van Loon (1942) sê:

Het Algemeen Reglement was het resultaat van de miskenning van het eigenaardig recht der kerk, dat door de machtsoverschrijding van de overheid werd gekrenkt, waarbij de kerkenorde van de belijdenis geisoleerd en het ambt gedegradeert werd. (p. 222)

Dit is verder te verwagte dat die volksplanting in Suid-Afrika aan die Kaap sedert 06 April 1652, later ook kerkregtelik gesproke, die model van die Algemeen Reglement sou navolg soos blyk uit die Provisioneele Kerken-Ordre van
1804 (Pont 1991:178), gevolg deur die Algemeen Reglement van 1824 (Pont 1991:216).

As gevolg van die feit dat die verhouding tussen kerk en owerheid aan die Kaap op gespanne voet beland het, sien Ordonnansie 7 van 1843 uiteindelik die lig wat die nuwe kerkwet van die Kaapkolonie bevat het.

Daarmee is die kerk aan die Kaap gedegradeer tot net nog 'n vrywillige vereniging synde:

$[R]$ ules and regulations of a merely voluntary association, and shall be capable of affecting the persons or properties of such persons only as shall be found in the course of any action or suit before any competent court to have subscribed, agreed to. (Pont 1991:258)

Hiermee het die patronaatsreg, net soos in die Dordtse Kerkorde van 1618-1619, bly vassteek en kom dit by implikasie daarop neer dat die burgerlike wetgewing in die persoon van die regter van die hoogste hof, finale seggenskap in die kerk het (vgl. Smit 2018:4).

Waarop kom dit neer? Kerke wat in vergaderings byeenkom en bindende besluite neem wat selfs vir die kerk as geheel geld, op grond van die Skrif as Woord van God, kan nie sondermeer as kollegialisties uitgemaak word wat in die verlenging van die Algemeen Reglement van 1816 funksioneer nie. Verder is Kollegialisme en verenigingsreg ook nie noodwendig gelyk aan mekaar nie. Laasgenoemde is die manier hoe ook in Suid-Afrika regtens na die kerk gekyk en word uiteindelik vir sommige 'n manier om kerklike geskille by te lê. Ten spyte van die feit dat die kerk regtens so beskou word, hoef dit geen aanduiding van die wese van die kerk te wees nie, want kerkreg is ekklesiologie, die manier hoe die kerk homself sien. Smit (2018) sê:

[A] collegialistic concept of church dismantled the church of its identity as the body of Christ, the building of God, the temple of the Holy Spirit, the flock of Christ as the true Shepherd, et cetera, to a human society equal to all other human societies in the community. (p. 4)

Wie die kerke is en wat bedoel word om op 'n kollegialistiese patroon te funksioneer word nie aangedui nie, alhoewel Brown (1992:692) gemeen het die Nederduitse Gereformeerde Kerk en die Nederduitsch Hervormde Kerk van Afrika bedoel word. Indien kerke egter funksioneer op die basis soos gestel word deur Smit, hoef nie verder oor sodanige kerke debat gevoer te word nie, aangesien sulke kerke in elk geval vervlak en vervorm het tot niks meer as sosiale verenigings met 'n godsdienstige belang. Die belang en bruikbaarheid van kerkreg sal in sulke kerke nie hoog geskat word nie en daarom is die vraag na die verskraling van kerkreg in sulke kerke eintlik irrelevant. Die debat en kommer oor die belang van kerkreg is meer akuut in kerke wat hoegenaamd nie op 'n kollegialistiese wyse funksioneer nie en hulle ook nie as sodanig sien nie. Indien ekklesiologie in die kerklike-teologiese debat funksioneer en aandag kry, is kollegialisme in elke geval uitgesluit. 
Miskien moet tog maar aanvaar word dat ten minste in die debat oor Kollegialisme wat oor jare tussen die drie Afrikaanse hoofstroom kerke gevoer is, verskillende interpretasies van die saak die vermoë het om te duur (vgl. Spoelstra 1989:13-15). Brown (1992:709) wys daarop dat as van die kerk as collegium sprake is en verenigingsreg ter sprake kom soos die owerheid die kerk sien in die huidige bestel, 'dui dit nie sonder meer op die oriëntering van die Lutherse sisteem vir Duitsland nie', anders gestel is dit nie reglynig gelyk te stel aan Kollegialisme nie. Die mening word dus in die verband geboekstaaf dat geeneen van die bekende drie Afrikaanse kerke in Suid-Afrika kerkregtelik funksioneer op paradigma van die Kollegialisme nie.

\section{Independentisme}

Meegaande artikel wil die rede vir kerkordelike en kerkregtelike onderwaardering soek by wat genoem kan word ' $n$ hedendaagse Independentisme. Die oorspronge van Independentisme kan ver teruggevoer word tot in die sewentiende eeu in die jare 1640 tot 1660. Kerke in Amerika en Engeland wat op die manier ontstaan het was nou verbonde aan die gereformeerde leer op die Europese vasteland, maar het in verband met die kerkinrigting 'n eie weg gegaan (Deddens 1988:106-107). Gewoonlik word die name Independentisme en Kongregasionalisme deurmekaar gebruik (vgl. Van 't Spijker 1990:313). Beide name het betrekking op bepaalde sienswyses uit die geskiedenis wat dui op 'n eiesoortige siening oor kerkreg en kerkorde.

Kongregasionalisme vestig die aandag op die gemeente (of kongregatie) wat as sodanig die draer is van alle gesag. Independentisme daarteenoor, is meer afgestem op onafhanklikheid van elke vergadering van gelowiges:

De naam independentisme duidt op het feit, dat de gemeente daarbij niet afhankelijk is van een bisschop, van een synode, terwijl in wijdere zin ook de onafhankelijke opstelling ten opzichte van belijdenis en kerkverband een rol speelt. (Van 't Spijker 1990:313)

Die aksent by die Independentisme val op die onsigbare kerk, omdat slegs die waarlik wedergebore en beproefde Christene tot die kerk gereken kan word.

Die gemeente word georganiseer rondom 'n bepaalde 'Covenant', as 'n geheel op sigself staande gemeente waar die persoonlike omgang wesenlik is (Bronkhorst 1947:245). Van 't Spijker (1990:314) verwys na A. Kuyper en H.H. Kuyper se siening van Kongregasionalisme of Independentisme en vra die vraag of 'zich niet te veel lieten leiden door de Nederlandse kerkelijke situatie van het einde van de 19e eeuw.' Reeds tydens die regering van Elizabeth I in Engeland ontstaan afskeidings uit die Engelse staatskerk wat vanweë vervolging na Nederland uitwyk, met as woordvoerders Robert Browne (1550?-1633) in Middelburg, Francis Johnson in Amsterdam en John Robinson in Leiden (vgl. Bronkhorst 1947:244).

Deddens sit uiteen waarin Kongregasionalisme bestaan het, naamlik 'n beroep op die Nuwe Testamentiese kerkvorm wat uit gemeentes bestaan het wat nie aan sinodale strukture onderworpe was as onderdeel van 'n groter geheel nie. Daarnaas het die kerk beweeg van buitengewone ampsdraers in die Nuwe Testamentiese tydvak na gewone ampsdraers soos die geykte herder en leraar, asook ouderlinge en diakens. Insiggewend wys Deddens (1988:107) daarop dat onder andere die siening gehuldig is dat sinodes 'mogen niet beschouwd worden als ambtelijke vergaderingen en hebben geen "hoger" gezag.' De gemeente moes gevorm word deur ware en herkenbare belyers wat hulle in ' $n$ verbond afskei van die staatskerk en 'n eie gemeente konstitueer deur 'n openlik verklaarde verbond waardeur God gedien kan word (Van 't Spijker 1990:316). Die name van Amesius en Parker word ook in Nederland genoem waar dit veral Amesius was wat in Nederland, waar hy 'n professoraat beklee het vanaf 1622 tot 1632 , onder studente maar nie minder onder sy landgenote, die ideaal van 'n suiwere kerk, onafhanklik van die owerheid met 'n eie organisasie, bevorder het.

By die Kongregasionalisme of Independentisme het dit daarop neergekom dat alle kerklike gesag in die gemeente setel. 'Men kan de verhouding van de plaatselijke kerk tot de synode niet tekenen in termen van afhankelijkheid. Een kerk hangt volkomen van Christus af' (Van 't Spijker 1990:323). Die verklaring van afhanklikheid aan Christus alleen, klink bruikbaar, maar daarmee word 'n teologiese argument benut tot regverdiging van kerklike afskeiding, of anders gestel: 'n verweer aangebied waarom 'n eie pad bewandel word.

\section{Die huidige tendens gesien teen die kerkordelike verlede}

Die argument kan gevoer word dat net so min as wat Kollegialisme die oorsaak vir die huidige onderwaardering van kerkreg en kerkorde is, kan Independentisme of Kongregasionalisme daarvoor aangewend word. Dit aangesien beide genoemde stelsels dateer uit die negentiende en selfs uit die sewentiende eeu, laasgenoemde met verwysing na Independentisme. Dit word toegegee, maar die mening is tog dat Independentisme, nie in die vorm waarin dit ter sprake gekom het in die redelik ver kerklike verlede nie, maar die neiging tot afskeiding of distansiering van die groter geheel, 'n hedendaagse kerklike, of dan kerkordelike neiging is. In die gespanne verhoudinge wat in Nederland na die Doleansie van 1886 ontstaan het en in Suid-Afrika tot ' $n$ groot mate oorgeplant is, is die verwyt geredelik aangewend dat die Vryekerk wat deur Kuyper in Nederland na 1886 gevorm is, gebaseer was op Independentisme (Engelbrecht 1945:31).

Met die Kollegialisme of Independentisme as agtergrond, synde kerkordelike afwykings uit die gemeenskaplike kerklike verlede in gedagte, word in meegaande artikel gepoog om tot 'n antwoord te kom waarom kerkreg en kerkorde as sodanig, in die huidige kerklike bestaan nie in die nodige en bruikbare mate waardeer word nie. Onderwaardering van kerkordelike maatreëls in die huidige kerklike bestel in Suid-Afrika en volgens Koffeman (2009) ook in Europa, kom daarop neer dat ampsdraers of vergaderings van die ampte vir redes van hulle eie kies om 
vir geen besondere rede, net anders te handel of te besluit, of selfs niks te doen nie, afgesien van enige kerkordelike uitgangspunt.

Die uitdagings waarbinne die kerk hedendaags leef en wat getrotseer moet word om kerk te wees, is om die minste te sê uitdagend. Of dit meer of minder uitdagend is as wat die vroeë kerk beleef het in die eerste en tweede eeu na Christus, onder andere, is 'n oop vraag wat hierby gelaat word. Die mening kan ook gelug word dat die kerk eintlik nog nooit sonder uitdagings was nie en ook nie sal wees nie. Maar hiermee saam word die mening gestel dat uitdagende omstandighede waarin die kerk sy werk moet doen, nie hoef te beteken dat die kerkorde onderwaardeer en selfs nie meer normatief funksioneer nie, veral gesien in die lig van die feit dat 'n kerkorde so nou aan die Skrif, as ekklesiologie verbind is.

Dit is ' $n$ kerkordelike aanwysing dat nie 'n beroep op die burgerlike regspleging gedoen sal word nie, nie voor die kerklike weg volledig gevolg is nie (NHKA 2016:83, 86) (Ordereël 8.5.3; Ordinansie 8.1.5). Hoe jammer dit ook mag wees, maar die onvermydelike gebeur dat 'n beroep op die burgerlike wetgewing gedoen word (vgl. Van Wyk 2018:5-6). Die vraag kom in die verband ter sprake of die feit dat die kerk deur die burgerlike wetgewing, die owerheid dan, as 'n vrywillige vereniging beskou word in die samelewing, net soos enige ander vrywillige vereniging, nie meespreek tot ondergrawing van die kerk en alles wat sinoniem met kerk is nie. As die broederlike gesprek tussen lidmate en ampsdraers, asook vergaderings as kern van alle kerklike dissipline, nie meer bepalend geag word waartydens kerklike verskille en onvergenoegdhede uit die weg geruim kan word nie, dui dit op ' $n$ bepaalde hedendaagse Independentisme. Hedendaagse Independentisme dui op ' $n$ links laat of onderwaardering van die groter geheel, asook die besondere aard van die konteks waarbinne bestaan en geleef word. Anders gestel sou sodanige hedendaagse Independentisme neerkom op 'n ondergewaardeerde kerkbegrip. In die sin word die besondere relasie tussen Skrif en kerkorde nie gesien vir wat dit is nie, so asof dit alleen gaan oor die uiterlike samesyn van die kerk wat Sondae in 'n bepaalde gemeente sigbaar word.

Die situasie is dus nie te wyte aan Kollegialisme as gevolg van die Algemeen Reglement van 1816 wat onder die invloed van die Kollegialisme tot stand gekom het nie, maar as sovêr terug gegaan word, is dit waarskynlik eerder die invloed van die Algemeen Reglement met sy sterk teenwoordigheid van die owerheid wat onder die indruk verkeer het dat die destydse owerheid die kerk 'n besondere guns bewys het met die invoering van die Algemeen Reglement sonder dat die kerk daarin geken is. Die kerk het oor eeue te make gehad met die invloed van die owerheid soos die patronaatsreg in die Nederlandse situasie (vgl. Brown 1992:702) wat selfs in die Kerkorde van Dordt van 1618-19 opgeneem is (Art. IV, L) (Kersten 1980:177, 187). Die Kerkorde van Genève van 1541 (Ordonnances Ecclésiastique) waarin die invloed van Calvyn beduidend gegeld het, kom tot stand onder owerheidsinstemming en die owerheid doen mee aan visitasie deur twee lede van die Raad, saam met die ouderlinge
(Pont 1981:21, 27). Die teenwoordigheid van die owerheid het in die kerklike verlede hardnekkig bly voortduur sodat in dié sin tog ook raakpunte was, selfs tussen die Kerkorde van Dordt 1618-1619 en die Algemeen Reglement van 1816.

Billikheidshalwe is die owerheidssiening oor die kerk in Suid-Afrika nie 'n spreekwoordelike meulsteen om die nek nie, aangesien die owerheid in die vorm van die burgerlike regspleging nie daarop uit is om in kerklike aangeleenthede in te meng nie (ten minste tot op datum), maar word geen ander keuse gelaat indien vanuit kerklike geledere sodanige beroep gedoen word nie (vgl. 'Gays se regte vertrap' 2019:4).

\section{Ten slotte: terug by kerkordelike toleransie en die reg van usansie}

Die reg van usansie soos verwoord in Ordereël 10.5 van die Kerkorde van die Nederduitsch Hervormde Kerk is redelik genuanseerd van aard, maar ook duidelik omlyn as aanduiding dat optrede waarvoor die kerkorde nie voorsiening maak nie, hanteer word volgens die Skrif, in ooreenstemming met die belydenis van die Kerk, getrou aan die kerkorde terwyl die gebruike van die Kerk in ag geneem word. Dit kom eintlik daarop neer dat sodanige handelinge wat nie in die kerkorde opgeneem is nie, net so wel in die kerkorde opgeneem kon gewees het, maar nie is nie, omdat die kerkorde gebaseer is op die maksimum-minimum uitgangspunt wat daarop neerkom dat die kerkorde vir die Kerk en al sy gemeentes is en nie net vir een gemeente en sy besondere omstandighede nie.

Kerkordelike toleransie egter, gebeur net, sonder inagneming van die Kerk en sy orde, sodanig en in die mate soos wat dit nodig gevind word. Die gevaar hierin is dat ' $n$ bepaalde praktyk wat tot nadeel van die Kerk mag wees ontstaan en wanneer die probleem onder die opsig hanteer moet word, is die verweer dat dit kerkordelike usansie is, naamlik dat dit al lankal in die Kerk gebeur. Verder kan as verweer aangewend word dat ander praktyke toegelaat word en enige opsig oor bepaalde optrede as onregverdig en onewewigtig beskou kan word.

Dit moet beklemtoon word dat die reg van usansie en kerkordelike toleransie nie aan mekaar gelyk is nie. Die reg van usansie is nie tot nadeel van die Kerk en sy reg nie, omdat handelinge wat daaruit spruit wesenlik en op die keper beskou, steeds kerkordelik is. Die kommer gaan dus oor handelinge in die Kerk wat nie onder dié noemer tuis gebring kan word nie, maar plaasvind en maar net gelaat word.

Die vraag is waaraan dié toestand tewyte is. Tydens 'n vergadering van die Raad vir Kerkregtelike Advies wat jare lank in die NHKA funksioneer en die Kerk oor kerkregtelike aangeleenthe adviseer, gehou op 07 Februarie 2019, het die volgende menings as rede waaraan die situasie te wyte is, ter sprake gekom:

Morele waardes het verval en die gewete spreek dus nie meer so sterk nie; die Kerkorde word geïsoleerd van die Skrif beleef; niemand wil verantwoordelikheid aanvaar nie; sedert 1994 word 
geoordeel dat dit hoofsaaklik oor regte gaan eerder as verpligtinge; ampsdraers en lidmate word nie meer aangespreek vir versuim of onderwaardering van die Kerkorde nie, omdat gevrees word dat persone die Kerk gaan verlaat. ${ }^{1}$

Hierby kan seker gevoeg word dat die bewussyn van normatiewe gesag wat dan deur die kerkorde of bindende besluite van vergaderings geneem en vasgestel is, nie meer sterk genoeg funksioneer nie. Dat die tugkomitee wat sedert die laaste sinodale vergadering nuut saamgestel is, geen tugsaak hanteer het nie kan seker met dankbaarheid vermeld word, maar dit is waarskynlik nie die volle weergawe van die werklike toedrag van sake in die Kerk nie.

Dit is verder opvallend dat sommige onder die indruk verkeer dat die kerklike reg en derhalwe die kerkorde, verstaan en uitgelê moet word aan die hand van en teen die agtergrond van die burgerlike regspleging. Die reglynige beroep op die burgerlike regspleging wanneer' $n$ kerkordelike aangeleentheid ter sprake kom is riskant aangesien die persepsie geskep word dat die laaste woord oor kerkregtelike verskille in howe setel.

Verder word diegene wat 'n kerkordelike beroep doen by implikasie en by voorbaat na die burgerlike howe verwys.

Die gevolg is dus dat in kerkordelike dispute en verskille die neiging is om liewer te doen soos die regsgeleerde dit uitlê en verstaan veral wanneer die verwysing (waarskuwing) bygevoeg word dat wanneer die saak in 'n burgerklike hof aangehoor word, die regter dit inderdaad só sal sien. Derhalwe word sodoende by implikasie die laaste woord gespreek. Met verwysing na die regsverloop tussen die NHKA en die sogenaamde steedsHervormers, wat sedert die nege-en-sestigste Algemene Kerkvergadering wat in 2010 plaasgevind het, ontstaan het en nog nie afgehandel is nie, is dit duidelik dat kerklike sake liewer op kerklike wyse afgehandel moet word. Die bewuste of dalk onbewuste neiging in die Kerk deesdae is blykbaar dat elkeen wat oor enige saak' $n$ verskil van mening nahou, gereed staan om met die Kerk hof toe te gaan.

Die eietydse Independentisme wat in die artikel ter sprake gebring word, is tiperend van die kerklike praktyk tussen gemeentes en meerdere vergaderings, maar is waarskynlik die simptoom van 'n dieper liggende probleem, naamlik die Skrif en in die verlenging daarvan, die ekklesiologie wat grondliggend vir kerkorde en kerklike reg is, wat nie sterk genoeg ter sprake kom nie. Wanneer die kerkorde van sy bindinge losgemaak word en die bindinge nie meer normatief funksioneer nie, spel dit die dood in die pot vir die kerk. Hoe belangrik dit is om in die kerk te leef aan die hand van kerklike denke kan nie swaar genoeg beklemtoon word nie. Dalk word die besondere relasie tussen die kerkorde en die Skrif nie sterk genoeg beleef nie sodat die kerkorde nie normatief beleef en hanteer word nie.

1.Die Raad is tydens die een-en-sewentigste Algemene Kerkvergadering (2016) saamgestel uit: advokate J.D. Fourie en M. Barnard en as predikantslede drs. R.J. Jones en B.J. van Wyk, asook ds. L. Geel.
Die mening is dus dat die huidige toedrag van sake aan Independentisme te wyte is, maar nader besien 'n eietydse Independentisme, wat prakties gesproke beteken: ek maak wat ek wil en jy maak wat jy wil ('Ek maak wat ek wil' 2019:3; vgl. 'Morelexit' 2019:1). Op die manier is kerklike opsig en tug na die randakker van kerklike handelinge verskuif wat vir die Kerk rampspoedige gevolge kan inhou. Die mees kritieke vraag uiteindelik is 'n vraag na Skrifgesag in die huidige kerklike lewe. Per slot van rekening bestaan daar nie 'n ander vorm van gesag in die kerk nie. Die probleem ter sprake is nie 'n Nederlandse of Suid-Afrikaanse vraagstelling en waarneming nie, maar geld as sodanig en kom ter sprake waar kerklik gedink en geleef word. Die mening ten slotte dat Independentisme nie ' $n$ ou Nederlandse verskyning is nie, maar besig is om hedendaags in ' $n$ nuwe gewaad na vore te kom, is na kritiese evaluering kerkordelik te herken as die spreekwoordelike wolf in skaapklere.

\section{Erkenning Mededingende belange}

Die outeur verklaar dat hy geen finansiële of persoonlike verbintenis het met enige party wat hom nadelig kon beïnvloed in die skryf van hierdie artikel nie.

\section{Outeursbydrae}

B.J.v.W. was die enigste outeur betrokke by die skryf van die artikel.

\section{Etiese oorwegings}

Hierdie artikel volg alle etiese standaarde vir navorsing.

\section{Befondsing}

Hierdie navorsing het geen spesifieke toekenning ontvang van enige befondsingsagentskap in die openbare, kommersiële of nie-winsgewende sektore.

\section{Data beskikbaarheidsverklaring}

Data-deling is nie van toepassing op hierdie artikel nie, aangesien geen nuwe data in hierdie studie geskep of ontleed is nie.

\section{Vrywaring}

Die sienings en menings wat in hierdie artikel uitgedruk word, is dié van die outeur (s) en weerspieël nie noodwendig die amptelike beleid of posisie van enige geaffilieerde agentskap van die outeurs nie.

\section{Literatuurverwysings}

Bakker, W., 1988, 'Geschiedenis van de wetenschap van het kerkrecht', in W. van 't Spijker \& L.C. van Drimmelen (red.), Inleiding tot de studie van het Kerkrecht, pp. 20-31, Kok, Kampen.

Biesterveld, P. \& Kuyper, H.H., 1905, Kerkelijk Handboekje, Bos, Kampen.

Bouwman, M., 1937, Voetius over het gezag der synoden, Bakker, Amsterdam.

Bronkhorst, A.J., 1947, Schrift en kerkorde, Zuid-Holland, Den Haag. 
Bronkhorst, A.J., 1988, 'Schrift en Kerkorde', in W. van 't Spijker, \& L.C. van Drimmelen (red.), Inleiding tot de studie van het Kerkrecht, pp. 43-58, Kok, Kampen.

Brown, E., 1992, 'Die hervertolking van die paradigma in verband met die Kollegialisme om die Afrikaanse kerke kerkregtelik te verstaan', HTS 48(3\&4), 691-715. https:// doi.org/10.4102/hts.v48i3/4.2436

Coertzen, P., 1991, Gepas en ordelik, RGN, Pretoria.

Deddens, D., 1988, 'Het congregationalisme', in W. van 't Spijker, \& L.C. van Drimmelen (red.), Inleiding tot de studie van het Kerkrecht, pp. 106-109, Kok, Kampen.

De Wet, C.J.H., 1921, Die kollegiale kerkreg, Van Bottenburg, Amsterdam.

Dingemans, G.J.D., 1988, 'Kerkorde als ecclesiologische vormgeving', in W. van 't Spijker \& L.C.W. van Drimmelen, (red.), Inleiding tot de studie van het Kerkrecht pp. 207-220, Kok, Kampen.

'Ek maak wat ek wil, en jy maak wat jy wil', Die Hervormer, Mei 2019, p. 3.

'Die erediens in die NHKA', Die Hervormer, Januarie/Februarie 2019, p. 7.

Dingemans, G.J.D., 1988, 'Kerkorde als ecclesiologische vormgeving', in W. van 't Spijker, \& L.C. van Drimmelen (red.), Inleiding tot de studie van het Kerkrecht, pp. 207-220, Kok, Kampen.

Dunn, J.D.G., 2010, Unity and diversity in the New Testament, SCM, London.

Engelbrecht, S.P., 1945, Neo-calvinisme, ontwikkeling en afwyking, De Bussy, Pretoria. Fiolet, A., 1953, Een kerk in onrust om haar belijdenis, Callenbach, Nijkerk.

'Gays se regte vertrap', Beeld, 9 Maart 2019, p. 4.

Hooijer, C., 1848, Kerkelijke wetten voor de Hervormden in het koningrijk der Nederlanden, Noman \& Zoon, Zalt-Bommel.

Kersten, G.H., 1980, Kerkelijke handboekje, De Banier, Utrecht.

Kleyn, H.G., 1888, Algemeene kerk en plaatselijke gemeente, Morks, Dordrecht.

Koekemoer, J.H., 1994, 'Die idioom van die Nederduitsch Hervormde Kerk - 'n Teologiese vraag', HTS 50(1\&2), 14-26. https://doi.org/10.4102/hts.v50i1/2.2540

Koffeman, L.J., 2009, Het goed recht van de kerk, Kok, Kampen.

Kuyper, A., 1884, Tractaat van de Reformatie der kerken, Höveker \& Zoon, Amsterdam.

Le Roux du Plooy, A., 2012, 'Die hermeneutiek van gereformeerde kerkreg', In die Skriflig/In Luce Verbi 46(1), Art. \#36, 1-8. https://doi.org/10.4102/ids.v46i1.36

'Morelexit: “Dit is ons redes, plan"', Beeld, 7 Mei 2019, p. 1.
Nederduitsch Hervormde Kerk van Afrika (NHKA), 2016, '71ste Algemene Kerkvergadering', Kerkorde, Pretoria

Nederduitsch Hervormde Kerk van Afrika (NHKA) , 2018, 'Omsendskrywe 13/2018', Leierskap in die Kerk Pretoria.

Noordmans, O., 1984, Verzamelde werken, V, Kok, Kampen.

Oberholzer, J.P., 1999, 'Terug op die pad', in D.J.C. van Wyk (red.), 20ste eeu Hervormde Teologie, pp. 449-461, Sentik, Pretoria.

Oostenbrink-Evers, H., 2000, Beginselen en achtergrond van de Kerkorde van 1951 van de Nederlandse Hervormde Kerk, Boekencentrum, Zoetermeer.

Plomp, J., 1969, De kerkelijke tucht bij Calvijn, Academisch proefschrift, Vrije Universiteit te Amsterdam, Kok, Kampen.

Pont, A.D., 1981, Die historiese agtergronde van ons kerklike reg, Deel 1, HAUM, Pretoria. Pont, A.D., 1991, Die historiese agtergronde van ons kerklike reg, Deel 2, Kital, Pretoria.

Schlaich, K., 1969, Kollegialtheorie. Kirche, Recht und Staat in der Aufk/[ [rung, Claudius, München. (Ius Ecclesiasticum Bd. 8).

Smit, J., 2018, 'The decline of reformed church polity in South Africa', In die Skriflig 52(3), a2309. https://doi.org/10.4102/ids.v52i3.2309

Spoelstra, B., 1989, Gereformeerde kerkreg en kerkregering, V\&R, Pretoria.

Van de Beek, A., 1988, 'Hermeneutiek van het Kerkrecht', in W. van 't Spijker \& L.C. van Drimmelen (red.), Inleiding tot de studie van het Kerkrecht, pp. 59-72, Kok, Kampen.

Van Loon, J.C.A., 1942, Het algemeen reglement van 1816, Zomer \& Keuning, Wageningen.

Van 't Spijker, W., 1990, 'Congregationalisme', in W. van 't Spijker, W. Balke, K. Exalto \& L. Van Driel (red.), De Kerk, pp. 313-325, De Groot Goudriaan, Kampen.

Van Wyk, B.J., 1991, Die presbiteriaal-sinodale kerkbegrip, Kital, Pretoria.

Van Wyk, B.J., 2004, 'Die Kerkorde en die kerklike reg in die Nederduitsch Hervormde Kerk van Afrika aan die hand van die presbiteriaal-sinodale kerkbegrip', PhD-proefskrif, Universiteit van Pretoria.

Van Wyk, B.J., 2018, 'Die relevansie van kerkreg met besondere verwysing na die Nederduitsch Hervormde Kerk van Afrika', HTS Teologiese Studies/Theological Studies 74(4), a5118. https://doi.org/10.4102/hts.v74i4.5118 